Małgorzata Burzyńska

Specjalny Ośrodek Szkolno-Wychowawczy

im. Marii Grzegorzewskiej, Piła

\title{
TERAPEUTYCZNE ASPEKTY \\ NAUCZANIA JĘZYKA OBCEGO \\ DZIECI ZE SPECJALNYMI \\ POTRZEBAMI EDUKACYJNYMI (NA PRZYKŁADZIE UCZNIÓW \\ Z NIEPEŁNOSPRAWNOŚCIĄ \\ INTELEKTUALNA \\ W STOPNIU LEKKIM)
}

\begin{abstract}
Therapeutic aspects of teaching a foreign language to children with special educational needs taking as an example learners with mild intellectual disability
\end{abstract}

\begin{abstract}
The paper is an attempt to present an overall approach to special educational needs as revealed by children with mild intellectual disability in the course of learning a foreign language. It presents the results of an action research study conducted among primary special school pupils. The research aimed at identifying the possible range of basic skills involved in learning a foreign language, and in addition, determining the degree to which the foreign language stimulates the use of the mother tongue by those children. The paper also presents the limitations on the therapeutic aspects of teaching foreign languages to learners afflicted by intellectual disability.
\end{abstract}

\section{Wstęp}

Referat jest próbą całościowego ujęcia specjalnych potrzeb edukacyjnych, ujawnianych przez dzieci z niepełnosprawnością intelektualną w stopniu lekkim, w trakcie nauki języka obcego. Zaprezentowano w nim wyniki badania, prowadzonego metodą badania w działaniu w okresie dwóch lat, wśród uczniów uczęszczających do szkoły podstawowej specjalnej (klasa piąta i szósta), którego celem było zweryfikowanie, w jakim zakresie mogą oni opanować język obcy w 
podstawowych sprawnościach, a także, w jakim stopniu stymuluje on ich funkcjonowanie w języku ojczystym. Z tego względu przedstawię najpierw portrety wybranych uczniów z grupy badawczej, ze szczególnym uwzględnieniem indywidualnego charakteru ich specjalnych potrzeb edukacyjnych. Następnie omówię, w jakim wymiarze w sytuacji niepełnosprawności intelektualnej można wyznaczyć terapeutyczne aspekty nauczania języka obcego.

\section{Specjalne potrzeby edukacyjne ucznia $z$ niepełnosprawnością intelektualną}

Przyjęcie hipotez o podobieństwie struktury i sekwencji (por. Zigler i Hodapp 1986), pozwala uznać, że rozwój dzieci z niepełnosprawnością intelektualną ma podobną strukturę i przechodzi przez poszczególne stadia w takiej samej kolejności, jak u dzieci w normie intelektualnej. W takiej sytuacji można twierdzić, że zarówno dzieci o obniżonym, jak i te o przeciętnym poziomie inteligencji maja takie same potrzeby rozwojowe i edukacyjne. Ich spełnienie związane jest ze stworzeniem uczniom warunków, w których mogą doświadczać bezpieczeństwa, akceptacji, wsparcia, uznania oraz autonomii, umożliwiających im podejmowanie decyzji, gromadzenie pozytywnych doświadczeń i budowanie relacji międzyludzkich. W przypadku niepełnosprawności intelektualnej, już w dzieciństwie wiele dzieci nie może realizować wymienionych potrzeb, co może być związane $z$ występowaniem w ich rodzinach deficytów i dewiacji o charakterze uczuciowym i/lub materialnym. Dlatego, obok trudności w poznawaniu i rozumieniu świata, związanych z obniżonym poziomem rozwoju intelektualnego, uczniowie ci muszą zmagać się z brakiem wsparcia od osób najbliższych w realizacji celów, przyswajaniu nowych umiejętności i aktywnym współuczestniczeniu w życiu społecznym. Ogół negatywnych doświadczeń omawianej grupy dzieci może dopełniać świadomość własnej niepełnosprawności, nieustanne oczekiwanie porażki oraz wyuczona bezradność i przesadna zależność od innych, co często skutkuje kształtowaniem się nieadekwatnej samooceny $\mathrm{i}$ fałszywych modeli socjalizacji (por. Obuchowska 1991, Zigler i in. 1984).

Wielokontekstowe rozumienie niepełnosprawności intelektualnej pozwala na pogłębioną analizę specjalnych potrzeb edukacyjnych, dokonywaną w odniesieniu do każdego ucznia, który wymaga szczególnych metod, środków i warunków nauki, dostosowanych do jego możliwości, z powodu różnego rodzaju trudności rozwojowych. Konsekwencja tej analizy jest z jednej strony indywidualizacja nauczania/ uczenia sié, czyli próba zrozumienia potrzeb ucznia, w realizacji których natrafia na trudności. Z drugiej strony, pozwala na poszukiwania sposobów realizacji celów edukacyjnych i rehabilitacyjnych, które umożliwiają osiagnięcie sukcesu również uczniom o indywidualnym stylu rozwoju (por. Wojciechowski 2001). Wspieranie uczniów w zaspokojeniu specjalnych potrzeb edukacyjnych będzie 
wobec tego wiązało się z podkreśleniem ich podmiotowości, a jednocześnie organizowaniem nauczania/uczenia się w taki sposób, aby każdy z nich mógł, na miarę swoich możliwości, osiagać coraz lepsze wyniki i maksymalnie rozwijać się w dostępnym dla niego zakresie.

W tym kontekście można mówić o specjalnych potrzebach edukacyjnych każdego ucznia z niepełnosprawnością intelektualną w stopniu lekkim biorącego udział w badaniu, ujawnianych na lekcjach języka angielskiego, które zostaną zaprezentowane w formie wybranych charakterystyk (dokonanych na podstawie dokumentacji uczniów oraz własnych narzędzi badawczych ${ }^{1}$ ). Przedstawiony poniżej opis dotyczy dzieci w wieku 12-14 lat, realizujących obowiązek szkolny w szkole podstawowej specjalnej (klasa piąta i szósta):

Dominika $^{2}$ - w szerokim aspekcie, specjalne potrzeby edukacyjne uczennicy związane były z niekorzystną sytuacją rodzinną (pozbawienie rodziców praw rodzicielskich $z$ powodu przejawiania wobec niej i rodzeństwa przemocy i zaniedbań, uniemożliwiających zaspokojenie im podstawowych potrzeb), związaną z tym dwukrotną zmianą miejsca zamieszkania oraz szkoły, w której realizowała obowiązek szkolny. Negatywne doświadczenia w sferze społecznej wpłynęły na niechęć uczennicy do wyrażania własnych emocji, zmienne zaangażowanie w budowanie pozytywnych relacji z otoczeniem oraz silne doświadczanie własnej odmienności („w tej szkole wszyscy jesteśmy niepełnosprawni”). W zakresie funkcjonowania językowego, zgodnie $z$ diagnozą wstępną określono, że Dominika używała niewielkiej ilości słownictwa $z$ danych kręgów tematycznych, nie wskazywała nadawcy i odbiorcy wypowiedzi, a także borykała się z trudnościami w zakresie rozumienia poleceń słownych, gromadzenia informacji, ich porządkowania oraz zapamiętywania. Pomocy nauczyciela wymagała także jej umiejętność wyboru i oceny źródeł informacji oraz zastosowania wybranych sposobów uczenia się języka.

Jadwiga - złożoność specjalnych potrzeb edukacyjnych uczennicy wynikała ze świadomości własnej niepełnosprawności, braku wiary we własne możliwości oraz negatywnego obrazu jej samej („moja siostra jest ode mnie młodsza o 5 lat, a wie więcej niż ja, bo nie jest taka głupia”). Dodatkowo Jadwiga doświadczała negatywnej sytuacji rodzinnej, której największym problemem był niski status materialny oraz brak zainteresowania rodziców jej postępami oraz potrzeba wieloaspektowej pomocy. Niekorzystnym zjawiskiem dodatkowo osłabiającym postęp u uczennicy była słaba kontrola emocjonalna, niski poziom koncentracji na zadaniu, nierównomierny rozwój percepcji wzrokowej i koordynacji

1 Opracowany na potrzeby badania Arkusz diagnozy $i$ obserwacji postepón ucznia (zob. załącznik) umożliwił wszechstronne poznanie możliwości dzieci w sferze rozwoju poznawczego, językowego i komunikacyjnego oraz ustalenie na tej podstawie zindywidualizowanych form oddziaływań edukacyjno-terapeutycznych.

${ }^{2}$ Imiona dzieci zostały zmienione. 
wzrokowo-ruchowej, problemy w gromadzeniu i porządkowaniu wiedzy oraz niechęć do udziału w komunikacji. W płaszczyźnie funkcjonowania językowego na podstawie diagnozy wstępnej zaobserwowano zaburzenia w zakresie artykulacji, trudności w definiowaniu pojęć, słaby zakres słownictwa, brak umiejętności nazywania wybranych form wypowiedzi, niesystematyczne i mało dokładne wykorzystywanie posiadanej wiedzy w praktyce, a także problemy w zakresie wyszukiwania i porządkowania zdobytych informacji. Jednocześnie u Jadwigi zaobserwowano zmienną motywację do pracy na lekcji i natychmiastowe zniechęcenie w sytuacji zadań wymagających złożonych, wieloetapowych czynności.

Karol - silna potrzeba osiagnnięć, ujawnianych przez chłopca wiązała się z krótkim okresem koncentracji na zadaniu, wolnym tempem pracy, słabo rozwiniętą umiejętnością organizowania i porządkowania wiedzy, niskim poziomem rozwoju procesów poznawczych oraz percepcji wzrokowej i słuchowej. W aspekcie językowym trudności sprawiało mu prawidłowe posługiwanie się słownictwem, stosowanie zasad ortograficznych i gramatycznych środków językowych oraz wykorzystywanie w komunikacji kompetencji funkcjonalnej. W zakresie funkcjonowania komunikacyjnego słabe strony Karola dotyczyły umiejętności wyszukiwania i porządkowania informacji, wskazywania nadawcy i odbiorcy wypowiedzi oraz komunikowania własnych emocji. Obraz specjalnych potrzeb edukacyjnych dopełniały porażki chłopca w sytuacjach szkolnych (drugoroczność, powolny postęp przy dużym wysiłku), wyjątkowo niekorzystne doświadczenia rodzinne (zjawiska patologiczne w rodzinie, związane z uzależnieniem, agresją i brakiem umiejętności opieki nad dziećmi, skutkujące umieszczeniem ich w domu dziecka) oraz cechy osobowości, które powodowały przesadną uległość i zależność od innych, brak samodzielności w sytuacjach szkolnych oraz często ujawnianą bezradność.

Konrad - specjalne potrzeby edukacyjne ucznia były efektem trudności związanych z niepełnosprawnością intelektualną (obniżony poziom rozwoju poznawczego, deficyty percepcji wzrokowej i słuchowej, nieharmonijny rozwój funkcjonowania językowego m.in. słaby rozwój kontaktu słownego, trudności w rozumieniu poleceń, nie zawsze prawidłowe posługiwanie się słownictwem, opóźniony rozwój umiejętności czytania i pisania), niekorzystnymi doświadczeniami edukacyjnymi (powtarzanie klasy, etykieta najgorszego ucznia w klasie), słabym stopniem zainteresowania rodziców jego postępami (niepodejmowanie lub nieuzasadnione przerywanie wskazanych form terapii, odmowa wspólpracy $\mathrm{z}$ terapeutami) oraz $\mathrm{z}$ niechęcią do nawiązywania pozytywnych kontaktów społecznych (dodatkowo wzmagana przez silny stres ucznia wywołany wadą wymowy). Ogół negatywnych doświadczeń powodował nawarstwianie się zaległości programowych w szkole, coraz niższe 
zaangażowanie we współpracę i proponowane formy aktywności poznawczej, a jednocześnie narastanie zachowań nieakceptowanych społecznie.

Wskazane w ogólnym zakresie specjalne potrzeby edukacyjne, ujawniane przez dzieci objęte badaniem, pozwoliły na przyjęcie kilku założeń, na podstawie których planowano oddziaływania edukacyjne i rehabilitacyjne na lekcjach języka obcego:

- rodzaj trudności rozwojowych każdego ucznia, związanych z niepełnosprawnością intelektualną nie stanowi o niemożności osiagnięcia sukcesu w nauce języka obcego,

- każdy uczeń to jednostka w aspekcie biopsychospołecznym, która potrzebuje nie tylko dostosowanych do jego możliwości metod i form pracy, ale także pozytywnej atmosfery dla komunikacji i wielostronnego wspierania jego wysiłków,

- postępy każdego ucznia powinny być każdorazowo analizowane i oceniane w aspekcie indywidualnym, w porównaniu ze zmianami dokonującymi się w jego rozwoju,

- organizujac nauczanie/uczenie się należy brać pod uwagę ogół indywidualnego stylu rozwoju ucznia, ale także dodatkowe czynniki zewnętrzne, które moga stanowić przeszkody w realizacji celów edukacyjnych i rehabilitacyjnych, a tym samym dodatkowo obniżać efektywność nauczania,

- nauczając języka obcego dzieci z niepełnosprawnością intelektualną w stopniu lekkim należy umożliwiać im wielokontekstowe i systematyczne gromadzenie pozytywnych doświadczeń w nauce języka, a także wzbogacanie poznania dokonującego się za pośrednictwem języka.

Możliwości wspomagania uczniów z niepełnosprawnością intelektualną w realizacji specjalnych potrzeb edukacyjnych otwierają drogę do poszukiwania terapeutycznych aspektów nauczania języka obcego.

\section{Wspomaganie uczniów $\mathrm{z}$ niepełnosprawnością intelektualną $\mathbf{w}$ stopniu lekkim w realizacji specjalnych potrzeb edukacyjnych na lekcji języka obcego}

Nauczanie/uczenie się języka obcego dzieci z niepełnosprawnością intelektualną w stopniu lekkim może opierać się przede wszystkim na analizie ich specjalnych potrzeb edukacyjnych. Pozwala ona na wszechstronne poznanie ich możliwości, a także na poszukiwania zmierzające do stymulowania ich rozwoju w aspekcie językowym, dlatego „,ele edukacji muszq prz̨ede wszystkim uwggledniać rozwój tych cech, które sa nierozerwalnie zwiazane z rozwojem człowieczeństwa, a więc zdolność do myślenia pojeciowego i umiejętność komunikowania się" (Cunningham 1991: 23).

Zgodnie z założeniem, że realizacja specjalnych potrzeb edukacyjnych uczniów z niepełnosprawnością intelektualną powinna zachodzić w kontekście 
kompleksowego i interdyscyplinarnego wspomagania ich możliwości rozwojowych, można przyjąć, że cele realizowane na lekcjach języka obcego moga dotyczyć zarówno sfery edukacyjnej (nabywanie sprawności językowych w języku obcym oraz ich integrowanie), jak i rehabilitacyjnej (umożliwienia transferu strategii uczenia się języka obcego na doskonalenie kompetencji w języku ojczystym, poprzez celowe nakierowywanie uwagi na analogiczne zjawiska w obu językach) (por. Karpińska-Szaj 2006a, 2006b). W tej perspektywie, podstawowym celem omawianego badania, prowadzonego na lekcjach języka angielskiego z dziećmi $\mathrm{z}$ niepełnosprawnością intelektualną w stopniu lekkim, realizującymi obowiązek szkolny w szkole podstawowej specjalnej, było określenie, na ile nauka języka obcego może być komponentem ich postępu w edukacji i rehabilitacji. Tak zarysowana perspektywa umożliwiła podjęcie badania zmierzającego do określenia stopnia opanowania wybranych sprawności językowych w języku angielskim przez dzieci biorące udział w badaniu oraz możliwości wykorzystania nauczania/uczenia się języka obcego w całościowym usprawnianiu ich rozwoju poznawczego oraz funkcjonowania językowego w języku ojczystym.

Analizę przebiegu badania przestawię na przykładzie wybranych rodzajów ćwiczeń językowych o charakterze korekcyjno-kompensacyjnym, wybranych zgodnie ze specjalnymi potrzebami edukacyjnymi uczniów biorących udział w badaniu.

\section{Dominika}

- wspomaganie samodzielnej pracy nad rozwojem języka poprzez proponowanie uczennicy możliwości wykonania słownika słownoobrazkowego na podstawie własnego pomysłu:
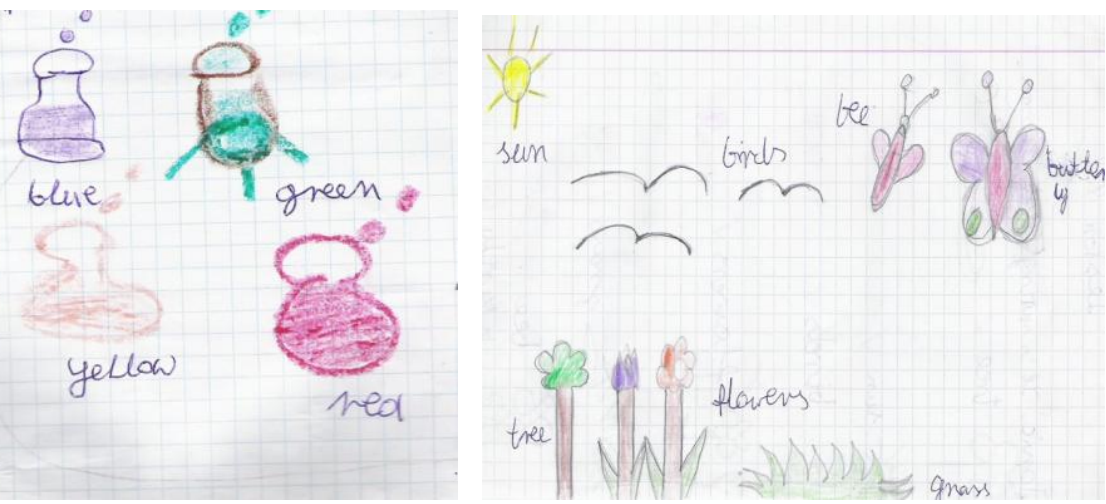

Rys. 1: Dominika: pierwsze samodzielne wykonanie słownika słowno-obrazkowego (technika samodzielnej pracy nad językiem)

- $\quad$ stymulowanie umiejętności wyszukiwania i porządkowania informacji: 


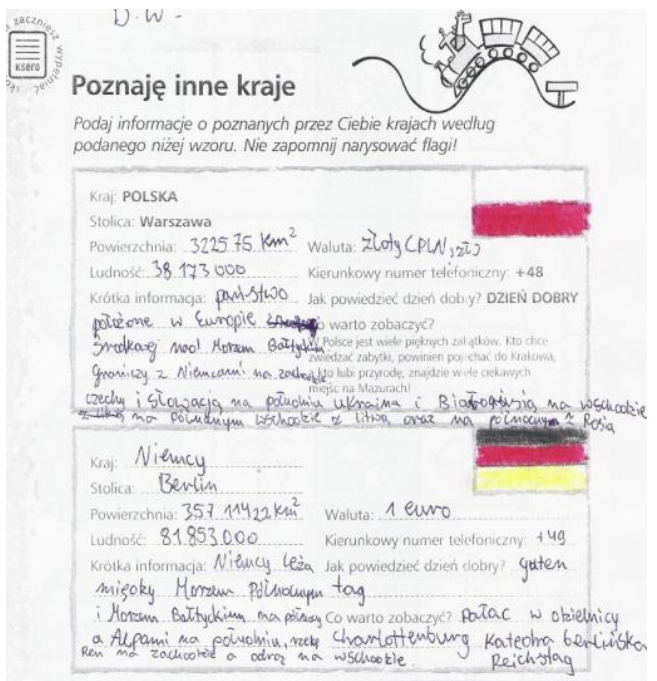

Rys. 2: Dominika: samodzielne uzupełnianie karty pracy do Portfolio z wykorzystaniem zasobów Internetu.

\section{Jadwiga}

- stymulowanie funkcjonowania komunikacyjnego poprzez korzystanie z formy zapisu (integrowanie sprawności):

2 Przeczytaj i napisz.

Bread and soup.

Yes. of course.

You re my best friend now!

Hello. Jrog.
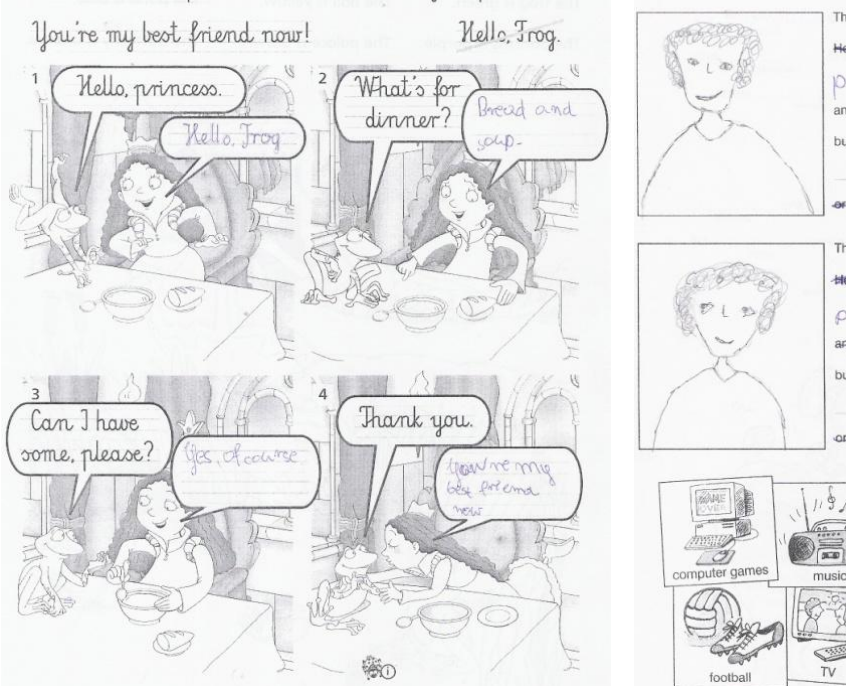

This is my friend Danka

He/She likes computer games, music

pets, goool books footoall TY

and spontes.

buthershe doesn't like smakes, Spiders.
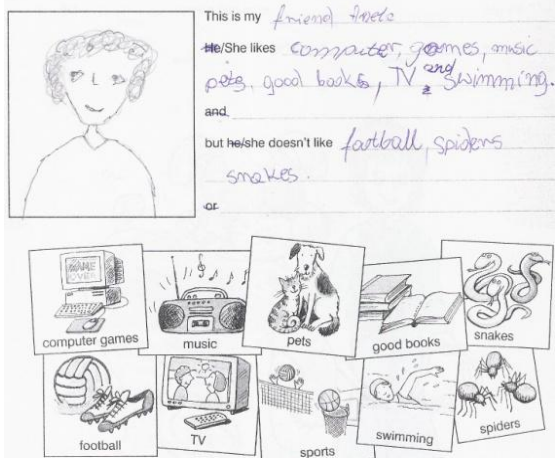
Rys. 3: Jadwiga: ćwiczenia wspomagające komunikację.

Konrad

- stymulowanie funkcjonowania językowego w aspekcie umiejętności semantycznych:

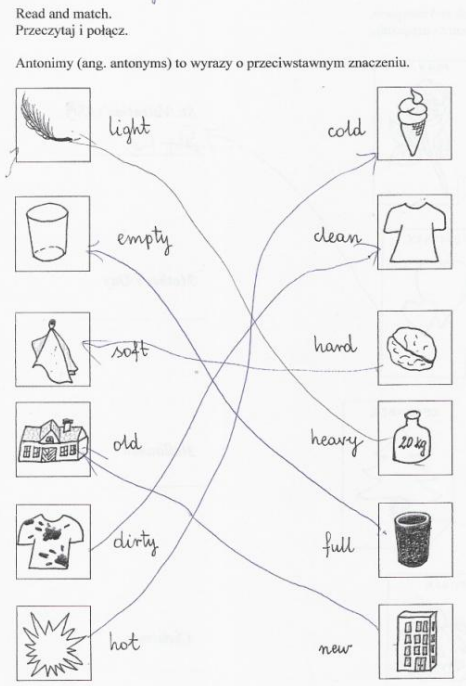

Rys. 4: Konrad: stosowanie antonimów z wykorzystaniem podanego słownictwa.

- stymulowanie funkcjonowania językowego w zakresie umiejętności leksykalnych:

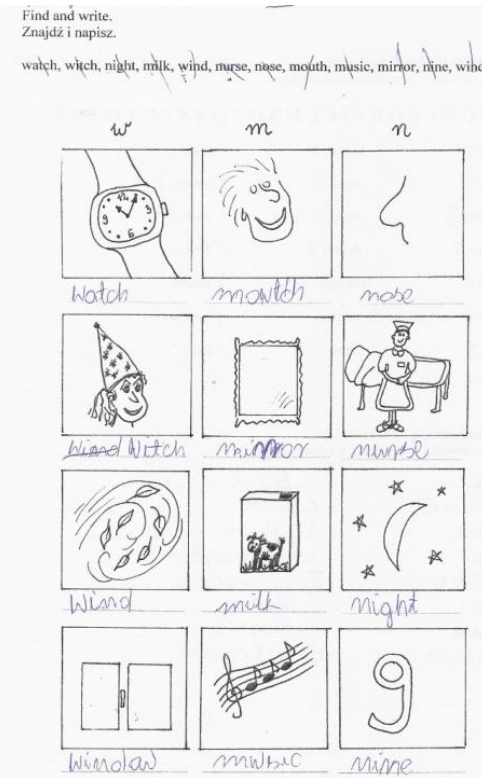


Rys. 5: Konrad: ćwiczenia utrwalające słownictwo, ćwiczenia w użyciu liter $m, n, w$.

Karol - stymulowanie funkcjonowania językowego w zakresie umiejętności leksykalnych oraz funkcjonowania poznawczego w zakresie porządkowania wiedzy:
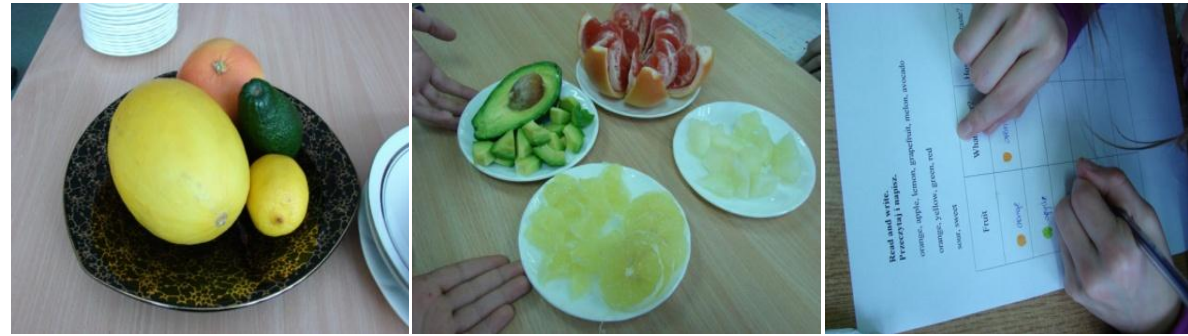

Rys. 6: Przykład zastosowania technik polisensorycznych w nauce słownictwa (przymiotniki).

\begin{tabular}{|c|c|c|}
\hline \multicolumn{3}{|c|}{$\begin{array}{l}\text { Read and write. } \\
\text { Przeczytaj i napisz. } \\
\text { orange, apple, lemon, grapefruit, melon, avocado } \\
\text { orange, yellow, green, red } \\
\text { sour, sweet }\end{array}$} \\
\hline Fruit & What colour? & How does it taste? \\
\hline orange 0 & Yolloar & $\begin{array}{l}\text { oronge } \\
\text { heet }\end{array}$ \\
\hline apple & $q l_{\alpha}$ & Sweet \\
\hline Kemon & yollow & sweet \\
\hline grapefruit & reed - & Sour \\
\hline melon & Hellow & Sweet \\
\hline avecado 8 & groeln & Sweit \\
\hline
\end{tabular}

Rys. 7. Karol: zapis danych w formie tabelarycznej na podstawie oceny polisensorycznej.

Przykładowe rodzaje ćwiczeń wykorzystywanych w trakcie prowadzenia badania są częściową ilustracją możliwości stymulowania rozwoju kompetencji językowych w języku ojczystym, podejmowanych na lekcjach języka obcego. W szerokim aspekcie, występowanie pozytywnego transferu między językami umożliwiło osiągnięcie postępów uczniów w następujących płaszczyznach:

a) funkcjonowania językowego:

- umiejętności leksykalnych: prawidłowego posługiwania się słownictwem, określania znaczenia słów z danych kręgów 
tematycznych, lepszej znajomości zbiorów leksykalnych związanych $\mathrm{z}$ najbliższym środowiskiem dziecka (członkowie rodziny, przybory szkolne, dni tygodnia, nazwy miesięcy, produkty żywnościowe),

- umiejetności gramatycznych: prawidłowego stosowanie gramatycznych środków językowych (elementów np. wyrazów; kategorii np. liczba pojedyncza i mnoga, mechanizmów np. stopniowanie), stosowania zasad wewnętrznej organizacji (większa wrażliwość na formy nieregularne),

- umiejetności semantycznych: używania słów zgodnie z ich znaczeniem oraz dostrzegania związków wewnątrzleksykalnych (synonimy, antonimy),

- umiejetnósci ortograficznych: stosowania zasad pisowni (wielkie litery w imionach, nazwiskach, nazwach państw i miast), używania wybranych znaków interpunkcyjnych, stosowania znaków logograficznych i symboli.

b) funkcjonowania komunikacyjnego:

- kompetencii socjolingwistycznej: wzmocnienie w zakresie użycia wybranych form grzecznościowych; stosowania formalnych i nieformalnych form adresatywnych;

- kompetencji funkcjonalnej: przekazywania informacji (pytanie/odpowiadanie); wyrażania życzeń i pragnień, komunikowania emocji, stosowania wybranych form wypowiedzi - opisu, instrukcji (przepisu), listu, dialogu,

- samooceny.

c) funkcjonowania poznawczego:

- operacii umystonych dokonywanych na materiale konkretnym: powolny postęp w zakresie wskazywania istotnych cech/związków przyczynowo skutkowych, określania cech ogólnych/podobieństw i różnic, rozumienia symboli graficznych,

- pamieci i unvagi: zapamiętywania/odtwarzania i wykorzystywania informacji, powolny postęp w skupieniu uwagi na zadaniu,

- percepiji warokowej $i$ stuchowej oraz koordynacji warokowo-stuchoworuchowej: lepsze rozpoznawanie schematu własnego ciała i stosunków przestrzennych, zróżnicowany postęp w zakresie rozpoznawania i identyfikacji dźwięków,

- umiejetności zdobywania wiedsy oraz operowania niq: dokonujące się z pomocą nauczyciela wybór źródła informacji i wykorzystywanie zdobytych informacji w praktyce,

- umiejetności porzadkowania wiedzy: lepszego grupowania słownictwa, zróżnicowany postęp zanotowano w zakresie łączenia wiedzy $\mathrm{z}$ różnych przedmiotów. 
Systematycznie stosowane, w trakcie prowadzenia badania, zindywidualizowane oddziaływania edukacyjno-terapeutyczne pozwoliły na osiagnięcie przez uczniów mierzalnych postępów zarówno w zakresie podstawowych sprawności w języku angielskim, a także w sferze funkcjonowania językowego w języku ojczystym. Przyjęte na potrzeby przeprowadzonego badania założenie o terapeutycznych aspektach nauczania języka obcego dzieci ze specjalnymi potrzebami edukacyjnymi pozwoliło na podkreślenie dynamicznej relacji rozwoju ich kompetencji językowych i czynności poznawczych.

Biorąc pod uwagę omówione możliwości wspomagania rozwoju funkcjonowania językowego, komunikacyjnego i poznawczego u dzieci z niepełnosprawnością intelektualną w stopniu lekkim, należy jednocześnie zaznaczyć, że trudno rozdzielić te sfery. Poprzez zadania, także językowe, proponowane dziecku ,doskonala sie operacje umystowe uczniów, zmieniaja sie jakościowo wszystkie procesy poznawcze, a wraz z. nimi myślenie, które staje sie bardziej samodzielna czynnościa poznawczq (...)” (Rakowska 2003: 128). W związku z tym podkreślone, na podstawie przeprowadzonego badania, możliwości uwypuklenia terapeutycznych aspektów nauczania języka obcego w edukacji dzieci z niepełnosprawnościa intelektualną w stopniu lekkim moga być odpowiedzią na ich specjalne potrzeby edukacyjne.

\section{Uwagi końcowe}

Prowadzone w trakcie omawianego badania poszukiwania możliwości usprawniania uczniów, zarówno w zakresie funkcjonowania językowego, komunikacyjnego oraz poznawczego, wpisują się w postulowana na gruncie pedagogiki specjalnej potrzebę wszechstronnego wspierania ich rozwoju, która może być realizowana również na lekcjach języka obcego. Zakłada ona konieczność podmiotowego traktowania wszystkich członków społeczeństwa oraz przełamywania stereotypu niepełnosprawności, jako zjawiska nieodłącznie związanego z ograniczeniami w aspekcie biopsychospołecznym. Stąd, przy analizie funkcjonowania jezzykowego dzieci ze specjalnymi potrzebami edukacyjnymi nie można jedynie dążyć do ,udokumentowania deficytów $i$ ich uwarunkowań, ukasywania stabych stron $i$ trudności (...) w porównaniu z osobami o prawidłowym rozwoju" (Bałachowicz i Paluszewski 1995: 5). Należy natomiast wykorzystywać wszelkie sposoby, umożliwiające wszechstronne wspomaganie rozwoju funkcjonowania językowego, komunikacyjnego i poznawczego, dokonującego się poprzez naukę języka. Wnioski z przeprowadzonego badania pozwalają przyjąć, że w sytuacji niepełnosprawności intelektualnej możliwości realizacji celów rehabilitacyjnych na lekcjach języka obcego są nadrzędne, ponieważ umożliwiają dzieciom rozwój ogólnych kompetencji poznawczych, niezbędnych dla prawidłowego funkcjonowania w języku ojczystym.

\section{BIBLIOGRAFIA}


Bałachowicz, J. i Paluszewski, J. (red). 1995. Sprawności jezylkowe drieci upośledzonych umystowo w stopniu lekkim. Warszawa: Wydawnictwo WSPS.

Cunningham, C. C. 1991. „Spojrzenie ponad patologię. Obecne tendencje w pedagogice specjalnej". Roczniki Pedagogiki Specjalnej t. 2. 23-37.

Karpińska-Szaj, K. 2006a. „Nauka języka obcego jako składnik rewalidacji mowy”. Scripta Neophililogica Posnaniensia, (red. S. Puppel) t. VIII. 49-58.

Karpińska-Szaj, K. 2006b. „Integracyjna koncepcja nauki języka obcego na potrzeby uczniów z niedoborami języka pierwszego", w: Krieger-Knieja, J. i Paprocka-Piotrowska U. (red.). Komunikacja jesylkowa w spoleczeństwie informacyjnym. Nowe wyzwania dla dydaktyki jesykón obcych. Lublin: Towarzystwo Naukowe KUL. 56-63.

Obuchowska I. 1991. „Dzieci upośledzone umysłowo w stopniu lekkim”, w: Obuchowska, I. (red.). Driecko niepetnospranne w rodzinie. Warszawa: WSiP. 199237.

Rakowska, A. 2003. Jezylk - komunikacja - niepetnosprawność. Wybrane zagadnienia. Kraków: Wydawnictwo Naukowe Akademii Pedagogicznej.

Wojciechowski, F. 2001. „Potrzeby specjalne i ich aplikacje w myśli pedagogicznej Prof. A. Hulka”, w: Dryżałowska, G. (red.). Paradygmaty i przeobrażenia edukacji specjalnej w snietle dorobku profesora Aleksandra Hulka. Materialy z. ogólnopolskie konferencii naukowej, Warszawa 24-25 maja 1999 r. Warszawa: Żak. 45-57.

Zigler, E., Balla, D. i Hodapp, R. 1984. „On the definition and classification of mental retardation". American Journal of Mental Deficiency vol. 89, 3. 215-230.

Zigler, E. i Hodapp, R. M. 1986. Understanding Mental Retardation. London: Cambridge University. 
Załącznik:

Arkusz diagnozy i obserwacji postępów ucznia (dokonywanej w celu ustalenia oddziaływań rehabilitacyjnych prowadzonych na lekcjach języka obcego)

\author{
I. Podstawowe dane o uczniu: \\ Imię: \\ Poziom rozwoju intelektualnego: \\ Rodzina: \\ Wcześniejsze doświadczenia edukacyjne: \\ Zajęcia specjalistyczne: \\ Niepełnosprawności dodatkowe: \\ Ogólna charakterystyka ucznia:
}

II. A. Rozwój języka ojczystego (funkcjonowanie w języku ojczystym w zakresie rozwoju podsystemów języka) (część arkusza wypełniana w porozumieniu z nauczycielem języka ojczystego)

\title{
1. kontakt słowny:
}

- wypowiada się spontanicznie (tak/nie/czasami ${ }^{3}$ )

- inicjuje rozmowę z kolegami/nauczycielem (tak/nie/czasami)

- podczas wypowiedzi zachowuje kontakt wzrokowy (tak/nie)

- rozumie polecenia nauczyciela (dot. konkretnych czynności w klasie) i wykonuje je

(tak/nie/czasami)

- wypowiada się tylko po naleganiach nauczyciela (tak/nie/czasami)

- większość wypowiedzi wymaga pomocy nauczyciela (tak/nie/czasami)

- nie chce, pomimo pomocy brać udziału w komunikacji (tak/nie/czasami)

- rozumie intencje wypowiedzi (tak/nie/czasami)

\section{2. artykulacja:}

- wady wymowy

- za szybkie tempo mówienia (tak - w jakich sytuacjach /nie),

- mówi za głośno, prawie krzyczy (tak/nie),

- mówi za cicho (tak/nie),

\section{3. długość wypowiedzi w sytuacji rozmów tematycznych na lekcji:}

(właściwe zaznaczyć wstawiając ' $x$ ')

- wypowiada się za pomocą kilku słów,

- wypowiada się za pomocą kilku zdań między którymi brak jest związku logicznego,

- wypowiada się za pomocą kilku zdań stanowiących całość logiczna,

- na pytanie odpowiada jednym słowem, ale z pomocą nauczyciela rozwija wypowiedź,

$3 \mathrm{~W}$ przypadku wyboru odpowiedzi czasami, proszę sprecyzować w jakich sytuacjach dane zachowanie jest przez ucznia przejawiane. 
- na pytanie odpowiada jednym słowem, znaczne trudności w rozwinięciu wypowiedzi nawet z pomocą nauczyciela,

- forma stylistyczna wypowiedzi jest prawidłowa (tak/nie),

\section{4. treść wypowiedzi:}

- jego wypowiedzi zawsze dotyczą treści zajęć (tak/nie/czasami),

- potrafi zadać właściwe pytanie do omawianego tematu (tak/nie/czasami),

- potrafi ująć związki przyczynowo-skutkowe (tak/nie/czasami),

- opisuje ilustrację za pomocą 1/2/3/4 zdań,

- wymienia przedmioty przedstawione na ilustracji (tak/nie),

- prawidłowo określa stosunki przestrzenne(tak/nie),

- nazywa cechy osób i przedmiotów oraz nazywa stany emocjonalne (tak/nie),

- dostrzega w tekście zależność zdarzeń (tak/nie/czasami),

\section{5. zasób słownikowy i umiejętność posługiwania się nim:}

- zakres używanego słownictwa (niski/przeciętny/dobry/bogaty),

- często używa właściwych nazw do określenia przedmiotów, zjawisk, osób (tak/nie),

- potrafi zdefiniować większość znanych pojęć (tak/nie),

- dobiera słownictwo zgodnie z podanym kryterium (np. zakres tematyczny)

(tak/nie/czasami),

- zawęża zakres znaczenia danych pojęć (tak/nie/czasami),

- rozszerza zakres znaczenia danych pojęć (tak/nie/czasami),

- wykorzystuje słownictwo z danych kręgów tematycznych (tak/nie/czasami),

\section{6. forma gramatyczna wypowiedzi:}

- prawidłowo używa czasu przeszłego, teraźniejszego, przyszłego (tak/nie/czasami),

- stosuje znaki przestankowe (tak/nie/czasami),

- dzieli wyrazy na sylaby, przenosi wyrazy w tekście pisanym (tak/nie/czasami),

- prawidłowo używa rzeczowników w liczbie pojedynczej i mnogiej (tak/nie/czasami),

- używa spójników do łączenia wyrazów (tak/nie/czasami),

- stosuje zasady pisowni wielką literą w imionach/nazwiskach/nazwach państw i miast (tak/nie/czasami)

\section{7. czytanie:}

- czyta sylaby/wyrazy/zdania,

- czyta poprzez głosowanie/sylabami/całościowo,

- wyszukuje dane informacje w przeczytanym tekście (tak/nie/czasami),

- układa pytania do tekstu i odpowiada na nie (tak/nie/czasami),

- czyta wyrazy/zdania ze zrozumieniem (tak/nie),

- koncentruje się na tekście czytanym przez nauczyciela (tak/nie),

- popełnia błędy w czytaniu (opuszcza litery/wyrazy, odgaduje dalszy ciąg wyrazu po

pierwszej literze/sylabie, myli formy fleksyjne),

- podejmuje próby samodzielnego czytania tekstu (tak/nie),

- posiada dobrą motywację do wykonywania ćwiczeń w czytaniu (tak/nie),

- wyszukuje w tekście wskazane litery i wyrazy (tak/nie) 


\section{8. pisanie:}

- pisze raz prawą raz lewą ręką (tak/nie)

- zna/nie zna wszystkich liter (jakich.........................), myli litery (które

- przepisuje tekst z tablicy/książki: często bezbłędnie/popełnia błędy (opuszcza litery, myli litery, zamienia kolejność liter, opuszcza wyrazy),

- pisząc zachowuje właściwą wielkość/kształt liter/proporcję/łączenia i

odstępy/prawidłowe rozmieszczenie tekstu na stronie

- pisze/nie pisze wyrazów i krótkich zdań z pamięci,

- pisząc z pamięci popełnia błędy (tak/nie/czasami)

- uzupełnia/nie uzupełnia wyrazów z zastosowaniem odpowiedniej końcówki w

zależności od przypadku i liczby,

- wolne tempo pisania (tak/nie),

- trudności w zapisie liter w liniaturze (tak/nie),

- posiada dobra motywację do wykonywania ćwiczeń pisemnych (tak/nie),

- pismo jest czytelne i staranne (tak/nie/czasami)

- opuszcza znaki interpunkcyjne i niewielki elementy graficzne (tak/nie/czasami)

\section{Proponowane ćwiczenia usprawniające sprawności językowe:}

\section{B. Funkcjonowanie komunikacyjne (zakładające funkcjonowanie społeczne):}

\section{1. funkcjonowanie społeczne:}

- nawiązuje pozytywne kontakty z kolegami z klasy i z nauczycielem (tak/nie),

- chętnie współpracuje w grupie (tak/nie/czasami),

- przestrzega ustalonych zasad pracy grupowej (tak/nie/czasami),

- jest obowiązkowy w zakresie przygotowania do lekcji i zadań wykonywanych na lekcji

(tak/nie/czasami),

- lubi kierować pracą w grupie (tak/nie/czasami),

- tworzy wypowiedź ze świadomością celu (tak/nie/czasami),

- używa form grzecznościowych (tak/nie/czasami),

- stosuje zasady przekazywania informacji (pyta i odpowiada) (tak/nie/czasami),

- stosuje/rozpoznaje wybrane formy wypowiedzi - opis/instrukcja/list

(tak/nie/czasami),

- wyszukuje wskazane wiadomości i porządkuje je (tak/nie/czasami),

- określa nadawcę i odbiorcę wypowiedzi (tak/nie/czasami),

- rozumie podstawowe komunikaty niewerbalne (tak/nie/czasami),

- rozróżnia zdania oznajmujące/pytające/rozkazujące (tak/nie/czasami),

\section{2. funkcjonowanie emocjonalno-motywacyjne:}

- chętnie podejmuje się wykonywania nowych zadań (tak/nie/czasami),

- doprowadza rozpoczęte zadanie do końca (tak/nie/czasami)

- zależy mu na otrzymywaniu pozytywnych ocen (tak/nie/czasami),

- adekwatnie ocenia własne możliwości (tak/nie/czasami),

- cechuje się dobrą motywacją do nauki (tak/nie/czasami),

- jest/stara się być samodzielny (tak/nie/czasami), 
- potrafi komunikować własne emocje (np. zadowolenie/niezadowolenie, wdzięczność) (tak/nie/czasami),

- wyraża własne życzenia/pragnienia (tak/nie/czasami),

\section{C. Funkcjonowanie poznawcze:}

1. rozwój operacji umysłowych (na podstawie działań na materiale konkretnym):

- wskazuje istotne cechy przedmiotów (tak/nie/czasami),

- rozumie proste zależności przyczynowo-skutkowe (tak/nie/czasami),

- klasyfikuje przedmioty według podanej cechy (tak/nie/czasami),

- potrafi wskazać cechy ogólne danej kategorii przedmiotów (tak/nie/czasami),

- szuka potencjalnych rozwiązań w sytuacjach problemowych (tak/nie/czasami),

- wskazuje podobieństwa i różnice między przedmiotami (tak/nie/czasami),

- rozumie znaczenie symboli graficznych (tak/nie)

\section{2. rozwój pamięci:}

- zapamiętuje najważniejsze informacje z lekcji (tak/nie/czasami),

- potrafi wykorzystać zapamiętane informacje w praktyce (tak/nie/czasami),

- zapamiętuje krótkie rymowanki i piosenki (tak/nie/czasami),

- zapamiętane informacje odtwarza ze zrozumieniem (tak/nie/czasami),

\section{3. rozwój uwagi:}

- potrafi skupić się na zadaniu (tak/nie/czasami),

- często jest zainteresowany przedmiotem lekcji (tak/nie/czasami),

- rozpraszaja go nawet słabe bodźce (tak/nie/czasami),

4. rozwój percepcji wzrokowej i słuchowej oraz koordynacja tych sfer:

- rysunki ucznia są dokładne i zawierają szczegóły (tak/nie/czasami),

- potrafi nazwać kierunki i określić stosunki przestrzenne (tak/nie/czasami),

- odwzorowuje proste wzory (tak/nie/czasami),

- odwzorowuje złożone wzory (tak/nie/czasami),

- rozpoznaje dźwięki z otoczenia/głosy kolegów z klasy (tak/nie/czasami),

- odtwarza prosty rytm i potrafi go przedstawić graficznie (tak/nie),

- pamięta szczególy oglądanego przedmiotu/ilustracji (tak/nie/czasami),

- odróżnia przedmioty zbliżone kształtem/wielkościa/kolorem (tak/nie/czasami)

\section{5. umiejętność organizowania i porządkowania wiedzy:}

- łączy słownictwo w zakresy tematyczne (tak/nie/czasami),

- potrafi powiązać temat lekcji z posiadaną wiedzą (tak/nie/czasami),

- potrafi dopasować zakresy tematyczne do danego działu nauczania (tak/nie/czasami),

- potrafi dobrać sytuacje komunikacyjne do danej tematyki (tak/nie/czasami),

- wykorzystuje/porządkuje zdobyte informacje (tak/nie/czasami),

\section{6. umiejętność zdobywania wiedzy:}

- wybiera źródło informacji adekwatnie do potrzeb (tak/nie/czasami),

- wie, że istnieją różne sposoby uczenia się języka (tak/nie/czasami),

- wykorzystuje w praktyce znane sposoby uczenia się języka (tak/nie/czasami), 
- samodzielnie pracuje nad doskonaleniem sprawności językowych (wykonuje dodatkowe ćwiczenia/poprawia własne błędy) (tak/nie/czasami),

III. Propozycja wykorzystania informacji o dziecku, zawartych we wstępnej diagnozie, do tworzenia indywidualnego programu nauczania języka obcego:

Dane ucznia:

Charakterystyka poziomu rozwojowego:

Mocne strony ucznia (zwłaszcza w zakresie funkcjonowania językowego):

Słabe strony ucznia (zwłaszcza w zakresie funkcjonowania językowego):

Zalecenia rehabilitacyjne na podstawie orzeczenia o potrzebie kształcenia specjalnego:

\begin{tabular}{|c|c|c|c|}
\hline $\begin{array}{l}\text { Cele } \\
\text { główne: }\end{array}$ & $\begin{array}{l}\text { Formy } \\
\text { indywidualizacji: }\end{array}$ & $\begin{array}{l}\text { Wybrane ćwiczenia } \\
\text { rehabilitacyjne, które moga być } \\
\text { stosowane na lekcjach języka } \\
\text { obcego: }\end{array}$ & $\begin{array}{l}\text { Prognozowane } \\
\text { osiagnięcia ucznia: }\end{array}$ \\
\hline $\begin{array}{l}\text { Cel } \\
\text { edukacyjny: }\end{array}$ & & & $\begin{array}{l}\text { W sferze rozwoju } \\
\text { języka obcego: } \\
\text { a) mówienie: } \\
\text { b) słuchanie: } \\
\text { c) czytanie } \\
\text { d) pisanie: } \\
\text { e) integrowanie } \\
\text { sprawności: }\end{array}$ \\
\hline $\begin{array}{l}\text { Cel } \\
\text { rehabilitacyjny: }\end{array}$ & & & $\begin{array}{l}\text { W aspekcie } \\
\text { rehabilitacyjnym - } \\
\text { rozwój języka } \\
\text { ojczystego } \\
\text { - funkcjonowanie } \\
\text { językowe: } \\
\text { - funkcjonowanie } \\
\text { komunikacyjne: } \\
\text { - funkcjonowanie } \\
\text { poznawcze: }\end{array}$ \\
\hline
\end{tabular}

IV. Propozycje analizy indywidualnych postępów ucznia zgodnie z programem nauczania

Arkusz obserwacji postępów ucznia

w zakresie funkcjonowania językowego w języku obcym zgodnie $z$ indywidualnym programem nauczania języka obcego

w trakcie roku szkolnego................... 


\begin{tabular}{|l|l|l|l|}
\hline $\begin{array}{l}\text { Zakres tematyczny } \\
\text { i kompetencyjny } \\
\text { (zgodnie z programem } \\
\text { nauczania) }\end{array}$ & $\begin{array}{l}\text { Wybrane słowa } \\
\text { i zwroty }\end{array}$ & $\begin{array}{l}\text { Poziom opanowania } \\
\text { wybranych słów i zwrotów }\end{array}$ & $\begin{array}{l}\text { Umiejętność } \\
\text { integrowania } \\
\text { sprawności }\end{array}$ \\
\hline & & & \\
\hline
\end{tabular}

\section{Wskazania do dalszej pracy:}

Wyjaśnienie symboli używanych do określenia zakresu nabywania poszczególnych sprawności przez ucznia:

1. Słuchanie i rozumienie:

a1 - słucha i rozumie

b1 - słucha i częściowo rozumie

c1- nie wie co oznacza po usłyszeniu

2. Czytanie i rozumienie:

a2 - czyta i rozumie

b2 - czyta i częściowo rozumie

c2 - nie wie co oznacza po przeczytaniu

3. Mówienie (produkcja)

a3 - mówi używając prostych zwrotów i słów

b3 - mówi używając niektórych słów

c3 - powtarza

\section{Mówienie (interakcja)}

a4 - uczestniczy w prostych sytuacjach komunikacyjnych

b4 - uczestniczy w prostych sytuacjach komunikacyjnych z pomocą nauczyciela

c4 - powtarza

\section{Pisanie:}

a5 - pisze wyrazy i podstawowe zdania (z możliwością odwołania się do wzoru)

b5 - uzupełnia tekst według wzoru

c5 - przepisuje tekst

Arkusz obserwacji postępów ucznia

w zakresie rozwoju funkcjonowania językowego $\mathrm{w}$ języku polskim

w trakcie roku szkolnego..................

Mocne strony ucznia:

Słabe strony ucznia:

Zalecenia rehabilitacyjne: 
Terapeutyczne aspekty nauczania języka obcego dzieci ze specjalnymi potrzebami ...

\begin{tabular}{|l|l|l|l|l|}
\hline $\begin{array}{l}\text { Zakres tematyczny } \\
\text { i kompetencyjny } \\
\text { (zgodnie z } \\
\text { programem } \\
\text { nauczania) }\end{array}$ & $\begin{array}{l}\text { Diagnoza } \\
\text { wstępna }\end{array}$ & $\begin{array}{l}\text { Prognozowane } \\
\text { osiagnięcia }\end{array}$ & $\begin{array}{l}\text { Wybrane ćwiczenia korekcyjno- } \\
\text { kompensacyjne oraz formy } \\
\text { indywidualizacji }\end{array}$ & $\begin{array}{l}\text { Diagnoza końcowa } \\
\text { (dotyczy wiedzy i } \\
\text { sprawności w języku } \\
\text { ojczystym) }\end{array}$ \\
\hline & & & & \\
\hline
\end{tabular}

Wskazania do dalszej pracy:

Arkusz obserwacji postępów ucznia

(w zakresie dynamiki rozwoju funkcjonowania językowego)

zgodnie $\mathrm{z}$ indywidualnym programem nauczania języka obcego

w trakcie roku szkolnego....................

\begin{tabular}{|l|l|l|l|l|l|l|l|l|l|l|l|}
\hline $\begin{array}{l}\text { Piesiace } \\
\text { Postepy } \\
\text { ucznia: }\end{array}$ & IX & X & XI & XII & I & II & III & IV & V & VI & \\
\hline $\begin{array}{l}\text { w zakresie } \\
\text { stopnia opanowania } \\
\text { jezzyka obcego: } \\
\text { 5. }\end{array}$ \\
\hline 1. czytanie
\end{tabular}




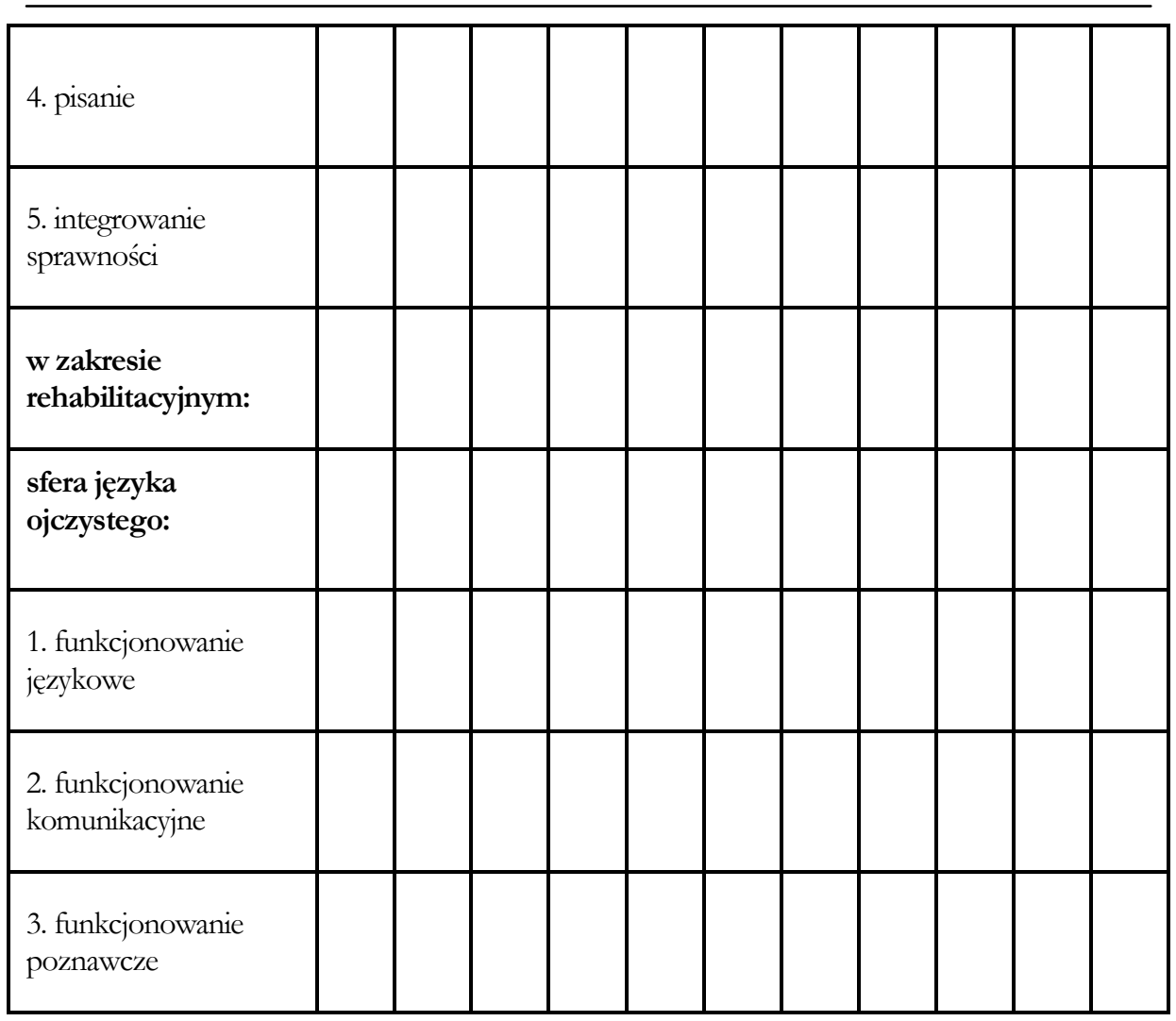

Punktacja za poszczególne osiąnięcia:

1 - duże trudności nawet z pomocą nauczyciela

2 - powolny postęp z pomocą nauczyciela

3 - dostateczny postęp z próbami samodzielnego działania

4 - dobry postęp z zauważalnymi błędami przy minimalnej pomocy nauczyciela

5 - szybki postęp z niewielkimi błędami, wysoki stopień samodzielności 